\title{
Synthesis of a Glucagon Receptor Antagonist
}
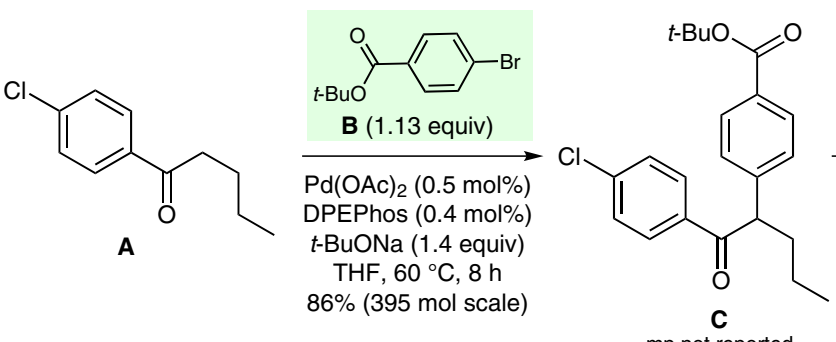

mp not reported
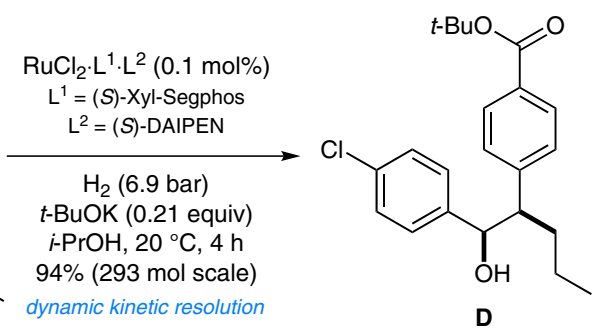

D

mp not reported $98.5 \%$ ee, $99.5 \%$ de

$\mathrm{H}_{3} \mathrm{PO}_{4}$ (10 equiv) $\mathrm{MeCN}, 62-68^{\circ} \mathrm{C}, 3.5 \mathrm{~h}$<smiles>CCC[C@@H](c1ccc(C(=O)O)cc1)C(c1ccc(Cl)cc1)c1cn(S(C)(=O)=O)c2c(F)cc(C)cc12</smiles>

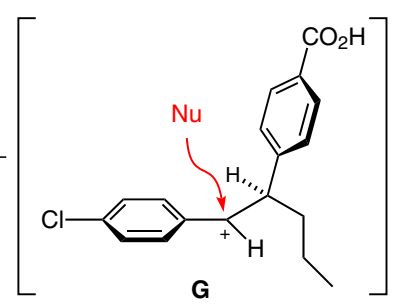

H

mp not reported $\mathrm{dr}>99: 1$ after crystallization
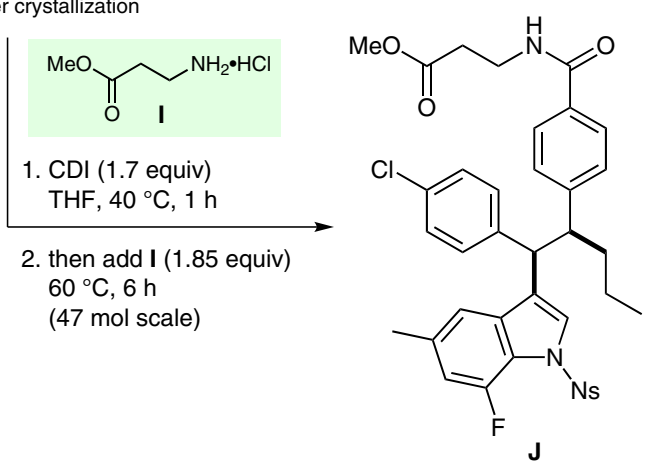

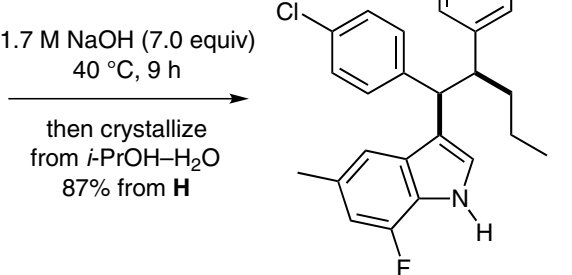

Glucagon Receptor Antagonist $\mathrm{mp}$ not reported
Gategory

Synthesis of Natural

Products and

Potential Drugs

\section{Key words}

glucagon receptor antagonists

Friedel-Crafts alkylation

palladium-catalyzed enolate arylation

Noyori asymmetric hydrogenation

dynamic kinetic resolution

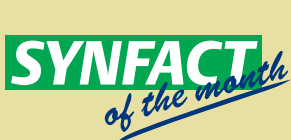

Significance: The target glucagon receptor antagonist is a candidate for the treatment of type 2 diabetes. Key steps in the synthesis of the sterically congested 1,1,2-triarylalkane core are (1) the asymmetric Noyori hydrogenation of ketone $\mathbf{C}$ involving a dynamic kinetic resolution and (2) the anti-selective Friedel-Crafts alkylation of the fluoroindole $\mathbf{F}$ by chiral benzylic carbocation $\mathbf{G}$.
Comment: Optimal Friedel-Crafts diastereoselectivity and yield were achieved with nosyl-protected indole F using TFA as solvent and catalytic $\mathrm{MsOH}$. A highly efficient, large-scale Larock-type synthesis of fluoroindole $\mathbf{F}$ from 2-bromoaniline was also developed. For the stereochemistry of the anti-selective Friedel-Crafts alkylation, see: J. Y. L. Chung et al. Org. Lett. 2008, 10, 3037.

SYNFACTS Contributors: Philip Kocienski

Synfacts 2013, 9(2), 0119 Published online: 18.01.2013

Dol: 10.1055/s-0032-1318012; Reg-No.: K10812SF 